\title{
CRUSTACEA ISOPODA COLLECTED DURING THE OC/S "ALMIRANTE SALDANHA" CRUISES IN SOUTHERN SOUTH AMERICA. I, SPECIES OF SEROLIS (FLABELLIFERA, SEROLIDAE)
}

\author{
PLINIO SOARES MOREIRA
}

Instituto Oceanogräfico da Universidade de São Paulo

\section{SYNOPSIS}

This paper reports on part of the species of the marine isopod genus Serolis (Crustacea, Flabellifera, Serolidae) collected from benthic stations performed during one of the cruises of the Brazilian Navy Oc/S "Almirante Saldanha" along southern South America. The species reported are Serolis polaris Richardson, 1911, Serolis elliptica Sheppard, 1933, Serolis uaperta Moreira, 1971, and Serolis foresti Bastida \& Torti, 1970. A complete synonymy is given for each of these species, as well as the main distinctive characteristics enabling its ready recognition. Some remarks are provided on features not lengthned treated on previous accounts. The geographical distribution of all named taxa is given. Serolis uaperta is for the first time reported from off State of Rio Grande do Sul (Brazil) and Uruguay, extending considerably southernwards its southern limit of distribution. Both Serolis foresti and Serolis elliptica are also for the first time recorded from off Uruguay.

\section{INTRODUCTION}

Isopods collected from benthic stations performed during one of the cruises of the Brazilian Navy Oc/S "Almirante Saldanha" in the western South

PUBL. NO 377 DO INST. OCEAN. DA USP. 
Atlantic Ocean were available to the author for study. Among the collected isopods the genus Serolis Leach, 1818, is well represented in number of species and specimens. This genus is widely distributed in Southern Hemisphere, and is one of the most characteristic component of the benthos especially in the Antarctic and Sub-antarctic regions (Beddard, 1884; Sheppard, 1933; Bastida \& Torti, 1970; Moreira, in press).

The aim of the present paper is to report on part of the collected species of Serolis available to the author. The species reported are Serolis polaris Richardson, 1911, Serolis elliptica Sheppard, 1933, Serolis uaperta Moreira, 1971 and Serolis foresti Bastida \& Torti, 1970. The position and details of the stations are given in List of Stations.

Serolis polaris Richardson, 1911

(Fig. 1)

Serolis polaris Richardson, 1911, p. 396-398, fig. 1; Tattersal1, 1921, p. 227; Nierstrasz, 1931, p. 223; Sheppard, 1933, p. 256, 265, 278, 286, 290-292, 319, fig. 4c-f, p1. 14 (fig. 2); Mañe-Garzón, 1953, p. 5; Kussakin, 1967, p. 333, table 1; Bastida \& Torti, 1967, p. 31-40; 1970, p. 66, 70, 84-86, 90, 93, 101, figs 11, 14; Moreira, 1971a, p. 86, 87-90, 101, 102, p1s. 1-4, table 1; 1971b, p. 390; 1973, p. 109-119, table 1; $1974 a$, p. 1-3, p1. 1 (fig. 1); 1974d, p. 129-134, figs 35-52.

Serolis (Serolis) polaris, Nordenstam, 1933, p. 48, 50, 58-59.

TYPE LOCALITY - South Sandwich Islands (Richardson, 1911).

MATERIAL EXAMINED - St. 2822: 3 juveniles. St. 2823: 1 ovigerous female $13.5 \mathrm{~mm}$ long; 1 juvenile. St. 2846: 2 juveniles, of which 1 damaged. St. 2864: 2 juveniles. St. 2865: 1 young female $8.5 \mathrm{~mm}$ long with minute buds of oostegites; 1 juvenile. St. 2866: 1 ovigerous female $21.5 \mathrm{~mm}$ long; 1 juvenile. 


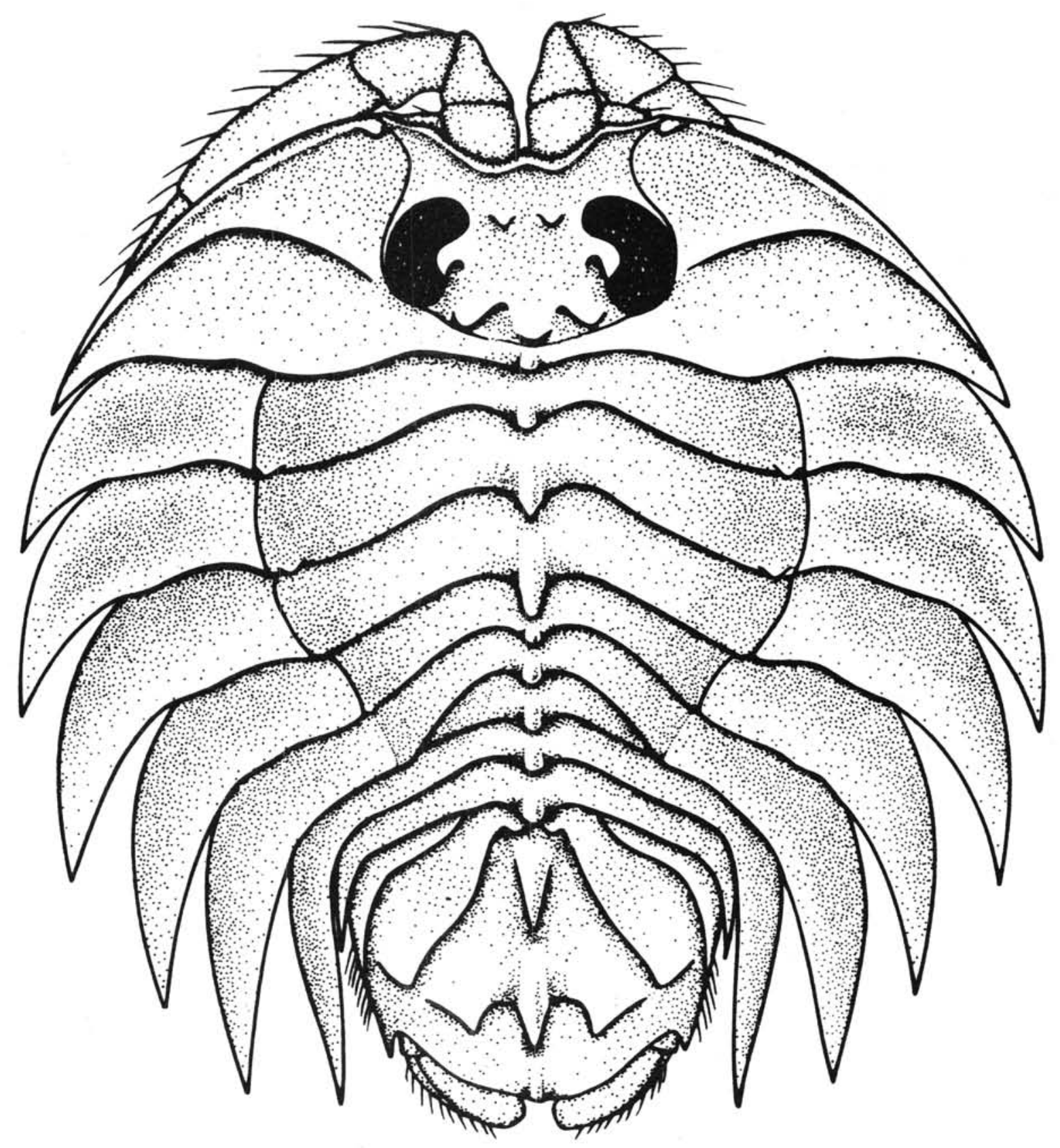

Fig. 1 - Serolis polaris Richardson, adult male, $16.0 \mathrm{~mm}$ long (from Moreira, 1971a; male specimen redrawned). 
Bolm Inst. oceanogr., S Paulo, 25, 1976

MAIN DISTINCTIVE CHARACTERISTICS - Body enlarged, almost circular, slightly convex. Head with 2 small anterior tubercles and 3 flattened posterior prominences. Antenna 2 with flagellar process. Maxilliped with distal epipod fused to endite, maxillipedal palp composed of 3 articles. Pereonites and pleonites each with 1 mid-distal tubercle extending posteriorly, that on pereonite IV larger and very prominent. Coxal plates of pereonites II-V marked off by dorsal sutures. Pereonite VI extending backwards to about apex of pleotelson, and to a level well beyond pleonite 3 but not beyond pleonite 2. Pleon with 3 free pleonites. Endopod of pleopod 4 bifid. Pleotelson with 1 strong mid-anterior spiniform tubercle flanked on either side by 1 small tubercle; from each of these tubercles extends a diagonal carina delimiting on either side a flat triangular area ending in a rounded point; slightly beyond these points are placed 3 spiniform tubercles interconnected by an arcuate transverse ridge; another carina, fading posteriorly, is placed on each pleotelson side following its anterolateral margins. Uropods biramous; endopod only slightly truncate distally, with both outer and inner distal angles broadly rounded.

GEOGRAPHICAL DISTRIBUTION - South Sandwich Islands (Richardson, 1911). Argentina (Nordenstam, 1933; Bastida \& Torti, 1967; 1970). Uruguay (Bastida \& Torti, 1970). Brazil (Bastida \& Torti, 1970; Moreira, 1971a, b; 1973; $1974 a, d)$. Present records: off southern Brazil and Uruguay. See Fig. 5.

REMARKS - This species is most closely related to Serolis schythei Lütken, 1858, from which it can be distinguished, among other features, by the relative length between pereonite VI and pleonite 2, shape of the endopod of uropod, and shape and development of tubercles on dorsum of each pereonite and pleonite (in S. schythei these tubercles are flattened, while in $S$. polaris they are prominent, oblique and somewhat spine-like, especial1y that on pereonite IV).

The color pattern of adult specimens was already described and figured. Moreira (1974a) has shown that in both adult males and ovigerous females it seems to have cryptic protective significance. In juveniles as small as $4.0 \mathrm{~mm}$ long, and in young females, the head and middle of pereon and pleon are yellowish with reddish-brown chromatophores forming a pigmented net- 
work; the body lateral areas are whitish, sometimes slightly yellowish; concentrations of pigments are placed distally on articles of peduncle of antenna 1 and 2, along distal margin of pereonites, on dorsum of pleotelson and as a single pigmented spot on the exopod of uropods.

It seems that females reache maturity at a very small size. Possibly a single female gets gravid several times, after each subsequent molt. The studied material seems to suggest that, since a female $8.5 \mathrm{~mm}$ long already have buds of oostegites, while 2 females each $13.5 \mathrm{~mm}$ and $21.5 \mathrm{~mm}$ long were gravid, bearing a we11 prominent marsupium.

Serolis elliptica Sheppard, 1933

(Fig. 2)

Serolis elliptica Sheppard, 1933, p. 256, 257, 261, 265, 270, 279, 301-304, figs 7-8; Bastida \& Torti, 1970, p. 67, 68, 99, 101, fig. 14; Moreira, $1971 a$, p. 100, table 5; 1974c, p. 109$110,111,112$, figs 22-30.

TYPE LOCALITY - South Atlantic, Lat. $52^{\circ} 00^{\prime} \mathrm{S}$, Long. $62^{\circ} 40^{\prime} \mathrm{W}$ (Moreira, in press).

MATERIAL EXAMINED - St. 2822: 2 females with developing oostegites, $2.8 \mathrm{~mm}$ and $2.9 \mathrm{~mm}$ long. St. 2823: 1 ovigerous female $3.0 \mathrm{~mm}$; 1 female with developing oostegites $2.6 \mathrm{~mm}$; 1 adult male $4.6 \mathrm{~mm} ; 2$ juveniles. St. 2846: 2 adult males, $3.8 \mathrm{~mm}$ and $4.1 \mathrm{~mm}$ long. St. 2864: 1 ovigerous female $3.1 \mathrm{~mm}$ long; 2 young males. St. 2866: 1 ovigerous female $3.3 \mathrm{~mm} ; 2$ adult males $3.6 \mathrm{~mm}$ and $4.0 \mathrm{~mm} ; 4$ young males.

MAIN DISTINCTIVE CHARACTERISTICS - Body elliptical, smooth, with coxal and pleural plates each contiguous laterally one to another. Antenna 2 with flagellar process. Maxilliped, distal epipod fused to endite, maxillipedal palp with 3 articles. Coxal plates of pereonites II-V marked off by dorsal sutures. Pereonite VI extending rearwards not beyond pleonites 2 and 3 , 
reaching back to about middle level of pleotelson. Pleon with 3 free pleonites. Pleotelson with a faint mid-longitudinal carina; posterolateral margins smooth, converging medially to a widely rounded apex; 1aterodistal angles very broad, flanked outwardly by a large spiniform point. Uropods biramous; protopod well developed, very broad, larger than exo- and endopod.

GEOGRAPHICAL DISTRIBUTION - Off Falkland Islands (Sheppard, 1933). South Patagonia (Moreira, in press). Brazil: off State of São Paulo, nearby I1ha Anchieta (Moreira, 1974c). Present records: off southern Brazil and Uruguay. See Fig. 6.

REMARKS - The most closely related species is Serolis completa Moreira, 1971, which may easily be distinguished from elliptica by the acutely pointed apex of pleotelson (in elliptica it is broadly rounded). Both species are very characteristic, and may at once be distinguished from all remainder ones of the genus by their elliptical body.

The examined specimens agree with previous descriptions. The body is well convex both dorsally and ventrally, especially in adult males and nongravid females, and densely fringed by short setae. The eyes are small, composite, black and only slightly prominent. The apex of pleotelson is broadly rounded, but in a large number of specimens it is minutely notched medially. Adult males cannot be distinguished from females by the shape of body, but they are distinctly longer than females. The adult males in the studied material are $3.6,3.8,4.0,4.1$ and $4.6 \mathrm{~mm}$ long, while the ovigerous females are $3.0,3.1$ and $3.3 \mathrm{~mm}$.

There is no available information about its color pattern. Some observations are provided here, based on alcohol preserved animals. The body ground color is yellowish, with small contracted black chromatophores distributed all over the body. The coxal and pleural plates are lighter and translucent. In a few specimens the color is dark-yellow, especially on middle of body. Juveniles and young are mostly whitish-yellow and transparent, chiefly the smaller ones.

S. elliptica is for the first time reported from off Uruguay at 30 and $40 \mathrm{~m}$ depth. 


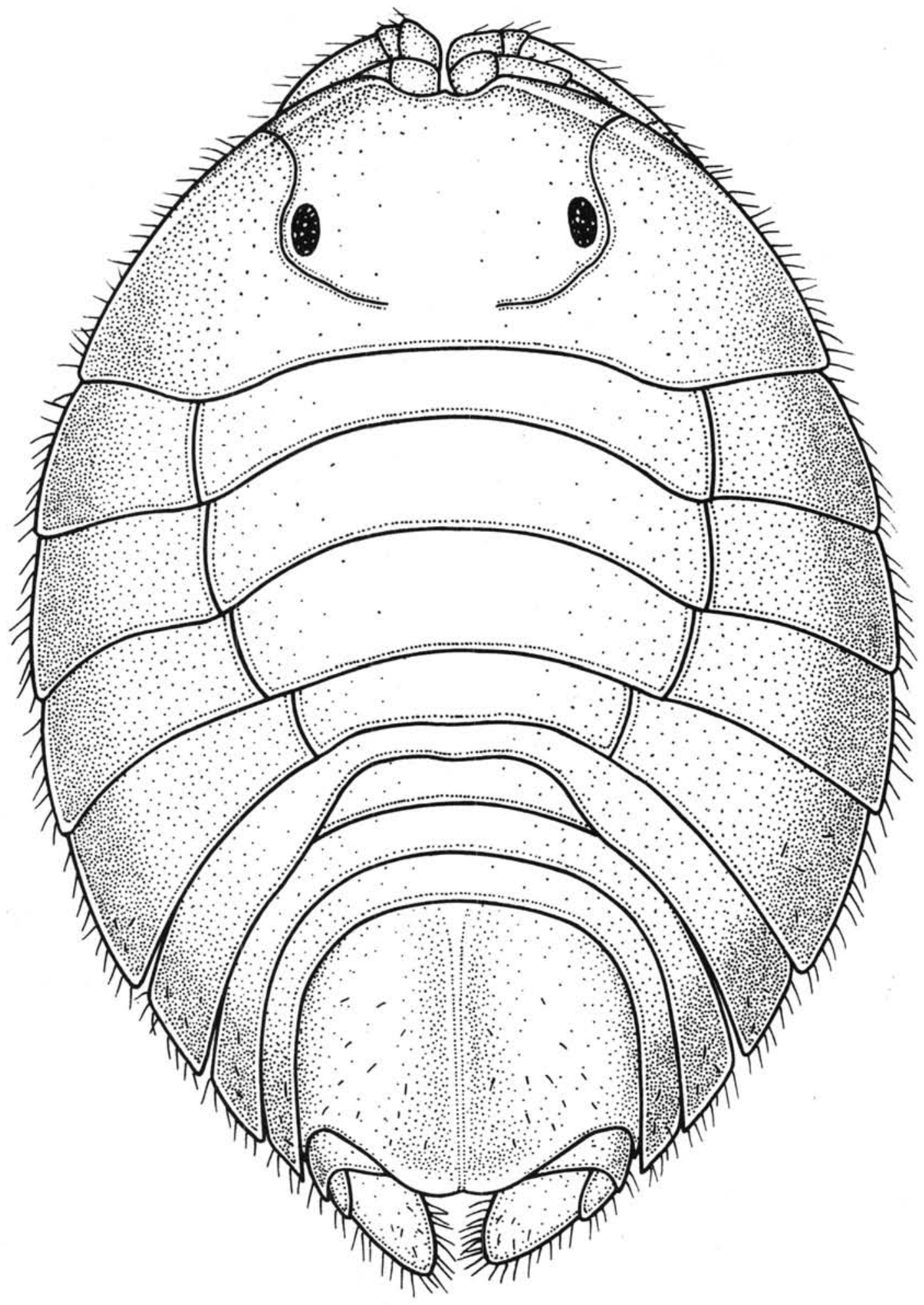

Fig. 2 - Serolis elliptica Sheppard, adult male, $4.0 \mathrm{~mm}$ long (from Moreira, 1974c). 
Serolis uaperta Moreira, 1971

(Fig. 3)

Serolis uaperta Moreira, 1971a, p. 86, 90-92, 101, 102, p1s 5-8, table 2; $1971 b$, p. 390; 1974d, p. 127, 128, 129.

TYPE LOCALITY - Brazi1, State of São Paulo, Ilha Anchieta, off Ponta do Catimbau to W, about Lat. $23^{\circ} 32^{\prime} \mathrm{s}$, Long. $45^{\circ} 02^{\prime} \mathrm{W}$ (Moreira, 1971 $a$ ).

MATERIAL EXAMINED - St. 2846: 1 female with developing oostegites $4.0 \mathrm{~mm}$ long. St. 2864: 1 adult male $4.1 \mathrm{~mm}$ 1ong. St. 2866: 2 ovigerous females $4.6 \mathrm{~mm}$ and $4.7 \mathrm{~mm}$ 1ong; 1 young male.

MAIN DISTINCTIVE CHARACTERISTICS - Body broad, well convex. Male posterior region of head, pereonites and pleonites with a mid-longitudinal carina extending backwards in a small point, which in the female is absent or slightly developed; distal point on male head spiniform and prominent. Antenna 2 devoid of flagellar process. Maxilliped with distal epipod fused to endite, maxillipedal palp 3-articulated. Coxal plates of pereonites II-IV marked off by dorsal sutures. Pereonite VI extending not beyond pleonites 2 and 3. Pleon with 3 free pleonites. Pleotelson U-shaped, well convex; hind margin smooth and broadly rounded, sometimes slightly pointed, especially in females; dorsal surface with 1 slight mid-1ongitudinal carina; on either side 1 arcuate diagonal ridge delimiting a shallow excavated area. Uropods biramous; both exo- and endopod distally broad and crenulated.

GEOGRAPHICAL DISTRIBUTION - Brazil: Rio de Janeiro (off Cabo São Tomé, Ilha Grande); São Paulo (off Ilha Anchieta, Ilha Vitória, and Ilha SumíticaIlha dos Búzios) (Moreira, 1971a). Present records: off southern Brazil and Uruguay. See Fig. 5.

REMARKS - This species is closely related to Serolis exigua Nordenstam, 1933, as already pointed out by Moreira (1971a, 1974d). It differs from exigua by a number of features, especially by the pattern of carinae on dorsum of pleotelson, shape of pleotelson, and antenna 2 devoid of flagellar process. 


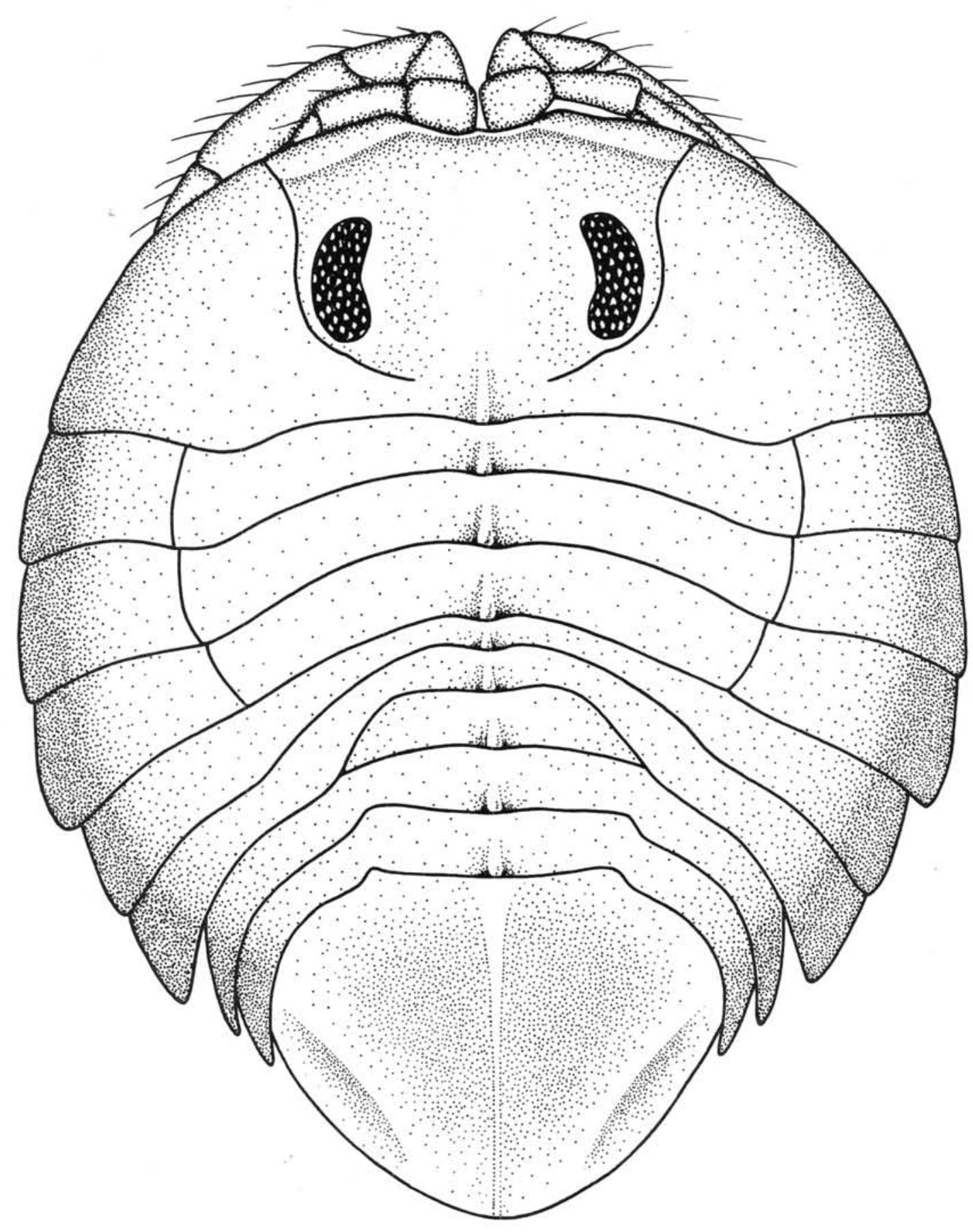

Fig. 3 - Serolis uaperta Moreira, adult male, $3.7 \mathrm{~mm}$ long (from Moreira, 1971a; male specimen redrawned). 
Adult males are broader than mature females (the male body is somewhat circular, while that of female is oval-shaped), and the head, pereonites and pleonites bear a carina ending in a tubercle like-point, which on head is prominent and spiniform, while in females these points are only slightly developed or absent. The shape of the pleotelson in the studied adult male is similar to that of the holotype male (Moreira, 1971a), while in the ovigerous females usually it is slightly pointed. The eyes are elongate and black. The pattern of carinae on dorsum of pleotelson is similar in both sexes, and agrees with that described for the holotype. The pleotelson is massive and arched, as it is also the body.

The color pattern is simple, and similar in males and females. The middle of head, pereon and pleon is yellowish, with the body lateral areas whitish. Pleotelson whitish-yellow. Chromatophores are absent, except distally on peduncular articles 4 and 5 of antenna 2, and more seldonly on head, where they forme a net-work. The appendages are whitish-yellow, but the protopod of the pleopod 2 of adult male bears distally a very striking brownish pigmented spot, absent in the young male and in the examined females.

The geographical distribution of the species has been considerably extended southernwards. Previously it was recorded from Rio de Janeiro and São Paulo, Brazil. The present occurrences extend its distribution to Rio Grande do Sul (Brazil) and Uruguay, from where it is reported for the first time. The Lat. $34^{\circ} 34^{\prime} \mathrm{S}$, Long. $52^{\circ} 52^{\prime} \mathrm{W}$ (St. 2864) is the present southernmost limit of occurrence of Serolis uaperta.

Serolis foresti Bastida \& Torti, 1970

(Fig. 4)

Serolis foresti Bastida \& Torti, 1970, p. 68, 70-75, 99, figs 2-4, 14; Moreira, 1974b, p. 90-94, figs 1-39; 1974d, p. 128, 133, 134. 


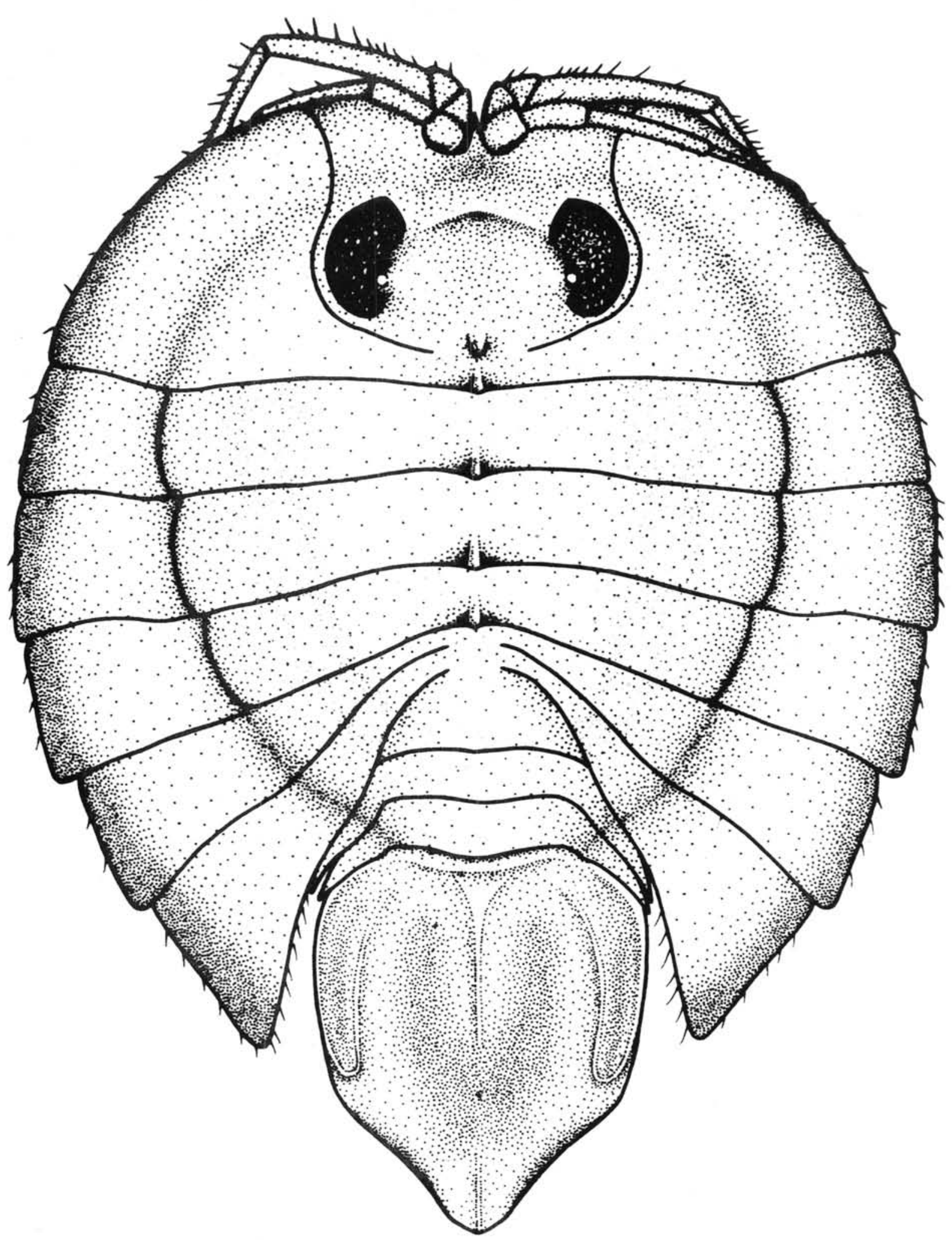

Fig. 4-Serolis foresti Bastida \& Torti, adult male, $5.5 \mathrm{~mm}$ long (from Moreira, 1974b). 


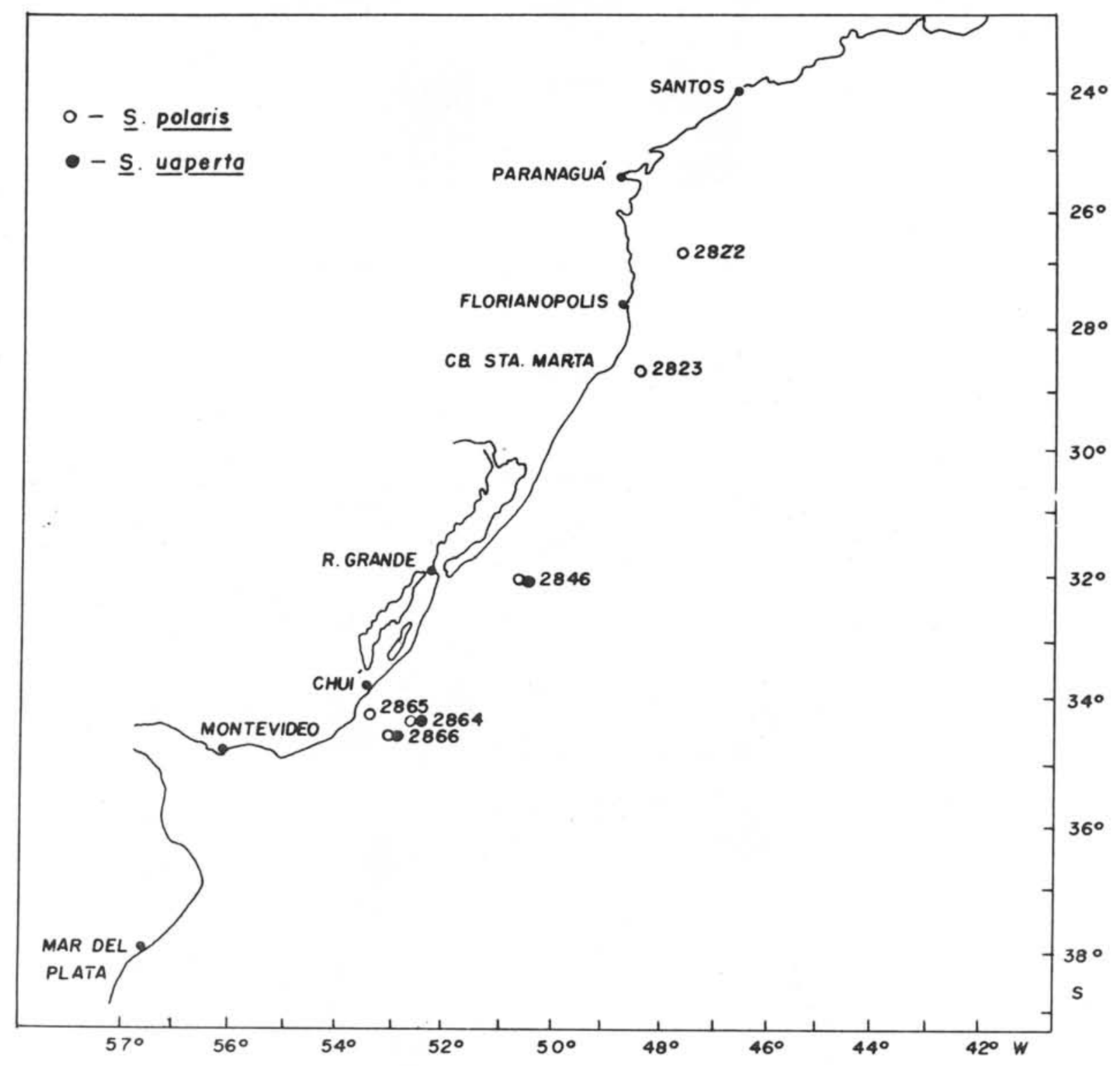

Fig. 5 - Distribution of Serolis polaris Richardson, and Serolis uaperta Moreira. Records based on specimens studied, collected by the 0c/S "Almirante Saldanha". 
TYPE LOCALITY - Off Argentina, Lat. $38^{\circ} 25^{\prime}$ S, Long. $56^{\circ} 14^{\prime}$ W (Bastida \& Torti, 1970).

MATERIAL EXAMINED - St. 2822: 1 adult male $5.6 \mathrm{~mm}$ long; 1 young male; 1 fragment of pleotelson. St. 2823: 1 female with developing oostegites $4.8 \mathrm{~mm}$ long. St. 2846: 1 spent female $7.0 \mathrm{~mm}$ long. St. 2864: 1 ovigerous female $5.8 \mathrm{~mm}$ long.

GEOGRAPHICAL DISTRIBUTION - Argentina (Bastida \& Torti, 1970). Brazil (off States of Rio de Janeiro and Rio Grande do Su1) (Moreira, 1974b, d). Present records: off southern Brazil (Rio Grande do Sul) and Uruguay. See Fig. 6 .

MAIN DISTINCTIVE CHARACTERISTICS - Head with a well marked, arcuate transverse carina forwardly placed between the eyes. Head and pereonites I-IV each with 1 small mid-distal ridge ending in a tubercle-like point about equal size, that on head slightly larger. Eyes composite, brownishblack, placed on projections raised up on inner side. Antenna 2 with flage1lar process. Maxilliped, distal epipod free; maxillipedal palp 2-articulate. Pereonites V-VI and pleonite 1 fused together at mid-1ine. Coxal plates marked off by dorsal sutures on pereonites II-IV. Pereonite VI extending rearwards to well beyond both pleonites 2 and 3, which are short, not exceeding anterolateral margins of pleotelson. Pleotelson roughly V-shaped, slightly concave dorsally, constricted at the lateroposterior margins; 1 distinct but not sharp mid-1ongitudinal carina interrupted by a smooth area about middle; 2 well marked carinae on either side joining posteriorly in a broad, rounded angle confining an elongate area; terminal portion vaulted, tumid, slightly upturned, ending in a short rounded-pointed apex, on either side of which the margins are distinctly straight. Uropods biramous; exopod much shorter than endopod.

REMARKS - This species seems very uniform regarding its general morphology and sculpturation of body. Bastida \& Torti (1970) and Moreira $(1974 b, d)$ detailled described and figured it. The rostrum is elongate and pointed, extending to distal angle of peduncular article 2 of antenna 1 . The 


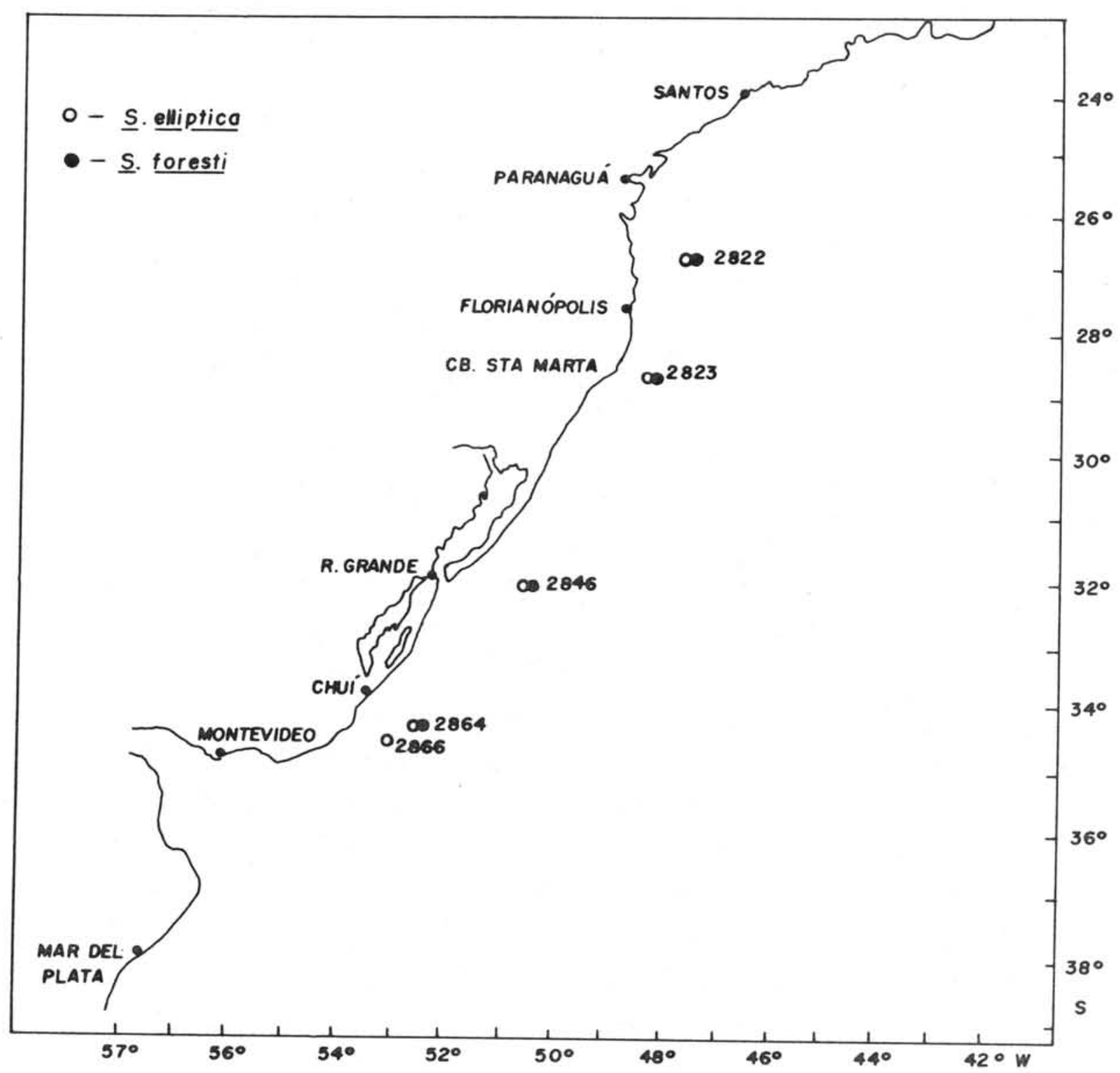

Fig. 6 - Distribution of Serolis elliptica Sheppard, and Serolis foresti Bastida $\&$ Torti. Records based on specimens studied, collected by the 0c/S "Almirante Saldanha". 
eyes are black, but in some specimens they are brownish depending on the concentration of the eyes pigment.

The color (in alcohol) is light brownish to yellowish on head, middle of pereon and pleon, and all over pleotelson, while the body lateral areas are whitish. The peduncular articles of both antennae 1 and 2 are light brownish, as well as the apex of the coxal plates of both pereonites $\mathrm{V}$ and VI. The ventral side of body is brownish-yellow, and so is the pleopod 4, but remainder appendages are whitish on its distal articles. Scattered single brownish chromatophores are located on head, middle of pereon, on 2nd peduncular article of antenna 1, middle of peduncular articles 4 and 5 of the antenna 2, and on the posterolateral margins of pleotelson.

S. foresti is for the first time reported from off Uruguay. Previously it has been recorded from Argentina and southern Brazil (Bastida \& Torti, 1970; Moreira, 1974b, d).

\section{RESUMO}

Estuda-se no presente trabalho parte do total das espécies de isópodes do gênero Serolis (Crustacea, Flabellifera) coletadas em algumas estações bênticas realizadas pelo N/Oc. "Almirante Saldanha" ao largo da costa ocidental da América do Sul. São as seguintes as espécies estudadas: Serolis polaris Richardson, 1911, Serolis elliptica Sheppard, 1933, Serolis uoperta Moreira, 1971 e Serolis foresti Bastida \& Torti, 1970.

Para cada espécie é dada completa sinonímia, assim como as principais características, possibilitando sua rāpida e fácil identificação. Igualmente, são feitas observações sobre características vārias ligeiramente mencionadas em trabalhos anteriores. Serolis uaperta é pela primeira vez assinalada ao largo do Estado do Rio Grande do Sul e Uruguai, o que vem estender consideravelmente o limite sul de ocorrência da espécie. Serolis foresti e Serolis elliptica são também, pela primeira vez, registradas ao largo do Uruguai. 


\section{ACKNOWLEDGEMENT}

The author is thankful to the Diretoria de Hidrografia e Navegação (DHN) of the Brazilian Navy for providing the specimens studied.

\section{LIST OF STATIONS}

St. 2822 - January 1972. $26^{\circ} 59^{\prime} \mathrm{s}, 47^{\circ} 53^{\prime}$ W. $85 \mathrm{~m}$ depth. $14.49^{\circ} \mathrm{C}$. $35.97 \mathrm{~s} \%$. Sand and silt. Rectangular dredge.
S. polaris
S. elliptica
S. foresti

St. 2823 - January 1972. $28^{\circ} 41^{\prime} \mathrm{S}, 48^{\circ} 25^{\prime} \mathrm{W} . \quad 60 \mathrm{~m}$ depth. $15.49^{\circ} \mathrm{C}$. $35.55 \mathrm{~S} \%$. $3.89 \mathrm{ml} / 1 \mathrm{O}_{2}$. Shell fragments, sand and silt. Rectangular dredge.
S. polaris
S. elliptica
S. foresti

St. 2846 - February 1972. $32^{\circ} 12^{\prime} \mathrm{s}, 50^{\circ} 54^{\prime} \mathrm{W} .72 \mathrm{~m}$ depth. $16.91^{\circ} \mathrm{C}$. $35.78 \mathrm{~s} \%$. Fine sand and silt. Rectangular dredge.
S. polaris
S. elliptica
S. uaperta
S. foresti

St. 2864 - February 1972. $34^{\circ} 34^{\prime} \mathrm{S}, 52^{\circ} 52^{\prime}$ W. $40 \mathrm{~m}$ depth. $33.52^{\circ} \mathrm{C}$. Fine sand. Rectangular dredge.
S. polaris
S. elliptica
S. uoperta
S. foresti

St. 2865 - February 1972. $34^{\circ} 33^{\prime} \mathrm{s}, 53^{\circ} 12^{\prime} \mathrm{W} .55 \mathrm{~m}$ depth. $17.41^{\circ} \mathrm{C}$. $33.04 \mathrm{~S} \%$. $4.35 \mathrm{ml} / 1 \mathrm{O}_{2}$. Fine sand and silt. Rectangular dredge.

S. polaris

St. 2866 - February 1972. $34^{\circ} 31^{\prime} \mathrm{s}, 53^{\circ} 28^{\prime}$ w. $30 \mathrm{~m}$ depth. $20.13^{\circ} \mathrm{C}$. $32.43 \mathrm{~S} / \% 0.4 .33 \mathrm{ml} / 1 \mathrm{O}_{2}$. Shell fragments. Rectangular dredge.
S. polaris
S. elliptica
S. uaperta 


\section{REFERENCES}

BASTIDA, R. \& TORTI, M. R. 1967. Nuevas consideraciones sobre SeroZis polaris Richardson, 1911. Neotrópica, 13(40):31-40.

1970. Crustaceos isopodos: Serolidae. Résult. scient. Camp. Calypso, no IX. Ann1s Inst. océanogr., Monaco, n.s., $47: 61-105$.

BEDDARD, F. E. 1884. Report on the Isopoda collected by H.M.S. "Challenger" during the years 1873-76. Part I. The genus Serolis. Rep. scient. Results Voy. H.M.S. Challenger, Zool., 11:1-83, p1s 1-10.

KUSSAKIN, 0. G. 1967. Isopoda and Tanaidacea from the coastal zones of the Antarctic and Subantarctic. In: Biological results of the Soviet Antarctic Expedition (1955-1958), 3. Issled. Faunei Morei, 4(12):220-380.

MAÑE-GARZON, F. 1953. Dos especies del genero Serolis de las aguas uruguayas. Comun. zoo1. Mus. Hist. nat. Montev., 4(69Bis):1-9, p1s 1-2.

MOREIRA, P. S. 1971a. Species of Serolis (Isopoda, Flabellifera) from southern Brazil. Bolm Inst. oceanogr., S Paulo, 20:85-144.

1971b. Espécies do gênero criófilo Serolis (Isopoda, Flabellifera) na plataforma continental centro-sul do Brasil. Ciênc. Cult., S Paulo, 23(sup1.): 390.

1973. The biology of species of Serolis (Crustacea, Isopoda, Flabellifera): reproductive behavior of Serolis polaris Richardson, 1911. Bolm Inst. oceanogr., S Paulo, 22:109-122.

1974a. Cryptic protective coloration in Serolis Zaevis and Serolis polaris (Isopoda, Flabellifera). Crustaceana, 27(1):1-4, p1. 1 .

1974b. A new record of species of Serolis (Crustacea, Isopoda, F1abellifera) from off southern Brazil. Bolm Inst. oceanogr., S Paulo, 23:89-101.

1974c. New records of species of Serolis (Crustacea, Isopoda, Flabellifera) from southern Brazil. Bolm Inst. oceanogr., S Paulo, 23:103-119.

1974d. New records and a new species of Serolis (Crustacea, Isopoda, Flabellifera) from southern Brazil. Bolm Inst. oceanogr., S Paulo, 23:121-153.

An account of the Serolidae (Crustacea, Isopoda, Flabellifera) collected by U.S. Antarctic Expeditions. Publção esp. Inst. oceanogr. S Paulo (in press). 
NIERSTRASZ, H. F. 1931. Die Isopoden der Siboga-Expedition III. Isopoda genuina. II. Flabellifera. Siboga Exped., Monogr. 32c:123-234, pls 10-11.

NORDENSTAM, A. 1933. Marine Isopoda of the families Serolidae, Idotheidae, Pseudidotheidae, Arcturidae, Parasellidae and Stenetriidae mainly from the South Atlantic. Further zool. Results Swed. Antarct. Exped., 3(1):1-284, p1s 1-2.

RICHARDSON, H. 1911. Isopodes du Sandwich du Sud. An. Mus. nac. Hist. nat. B. Aires, ser. 3, 14:395-400.

SHEPPARD, E. 1933. Isopoda Crustacea. Part I. The family Serolidae. "Discovery" Rep., 7:253-362, p1. 14.

TATTERSALL, W. M. 1921. Crustacea. Part VI. Tanaidacea and Isopoda. Br. Antarct. Terra Nova Exped. 1910, Zool., 3(8):191-258, pls 1-11.

(Recebido em 25/novembro/1974) 